\title{
Article \\ Effect of Freeze Crystallization on Quality Properties of Two Endemic Patagonian Berries Juices: Murta (Ugni molinae) and Arrayan (Luma apiculata)
}

\author{
María Guerra-Valle ${ }^{1,2}$, Siegried Lillo-Perez ${ }^{1,3}$, Guillermo Petzold ${ }^{1, *(\mathbb{D})}$ and Patricio Orellana-Palma ${ }^{4, * \mathbb{D}}$ \\ 1 Laboratory of Cryoconcentration, Department of Food Engineering, Universidad del Bío-Bío, Av. Andrés \\ Bello 720, 3780000 Chillán, Chile; maria.guerra1601@egresados.ubiobio.cl (M.G.-V.); \\ silillo@egresados.ubiobio.cl (S.L.-P.) \\ 2 Doctorado en Ingeniería de Alimentos, Universidad del Bío-Bío, Av. Andrés Bello 720, 3780000 Chillán, Chile \\ 3 Magíster en Ciencias e Ingeniería en Alimentos, Universidad del Bío-Bío, Av. Andrés Bello 720, \\ 3780000 Chillán, Chile \\ 4 Department of Biotechnology, Universidad Tecnológica Metropolitana, Las Palmeras 3360, P.O. Box, \\ 7800003 Nuñoa, Santiago, Chile \\ * Correspondence: gpetzold@ubiobio.cl (G.P.); p.orellanap@utem.cl (P.O.-P.); Tel.: +56-42-2463173 (G.P.); \\ +56-2-27877032 (P.O.-P.)
}

Citation: Guerra-Valle, M.; Lillo-Perez, S.; Petzold, G.; Orellana-Palma, P. Effect of Freeze Crystallization on Quality Properties of Two Endemic Patagonian Berries Juices: Murta (Ugni molinae) and Arrayan (Luma apiculata). Foods 2021, 10, 466. https://doi.org/10.3390/ foods10020466

Academic Editors: Asgar Farahnaky, Mohsen Gavahian and

Mahsa Majzoobi

Received: 25 January 2021

Accepted: 19 February 2021

Published: 20 February 2021

Publisher's Note: MDPI stays neutral with regard to jurisdictional claims in published maps and institutional affiliations.

Copyright: (c) 2021 by the authors. Licensee MDPI, Basel, Switzerland This article is an open access article distributed under the terms and conditions of the Creative Commons Attribution (CC BY) license (https:// creativecommons.org/licenses/by/ $4.0 /)$.

\begin{abstract}
This work studied the effects of centrifugal block freeze crystallization (CBFC) on physicochemical parameters, total phenolic compound content (TPCC), antioxidant activity (AA), and process parameters applied to fresh murta and arrayan juices. In the last cycle, for fresh murta and arrayan juices, the total soluble solids (TSS) showed values close to 48 and 54 Brix, and TPCC exhibited values of approximately 20 and $66 \mathrm{mg}$ gallic acid equivalents/100 grams dry matter (d.m.) for total polyphenol content, 13 and $25 \mathrm{mg}$ cyanidin-3-glucoside equivalents/100 grams d.m. for total anthocyanin content, and 9 and $17 \mathrm{mg}$ quercetin equivalents/100 grams d.m. for total flavonoid content, respectively. Moreover, the TPCC retention indicated values over $78 \%$ for murta juice, and $82 \%$ for arrayan juice. Similarly, the AA presented an increase over 2.1 times in relation to the correspondent initial AA value. Thus, the process parameters values were between $69 \%$ and $85 \%$ for efficiency, $70 \%$ and $88 \%$ for percentage of concentrate, and $0.72 \%$ and 0.88 (kg solutes $/ \mathrm{kg}$ initial solutes) for solute yield. Therefore, this work provides insight about CBFC on valuable properties in fresh Patagonian berries juices, for future applications in health and industrial scale.
\end{abstract}

Keywords: freeze crystallization; murta; arrayan; physicochemical properties; bioactive compounds; antioxidant activity; process parameters

\section{Introduction}

In the last decades, berries have gained a lot of attention due to their attractive colors, interesting physicochemical properties, and excellent nutritional and organoleptic characteristics. Thus, berries are not only consumed for their physical appearance but also for their countless and positive effects on the consumers' health, since these fruits have a significant source of micronutrients, phenolic compounds, and antioxidant activity that provide important beneficial effects for human health [1,2].

In this context, Chile has an important diversity of wild and endemic berries due to the different ecosystems of each region, since Chile presents from dry desert climate (North) to high-intensity rainfall rate and low temperatures (South) [3]. Hence, in southern-central Chile, there are various endemic berries such as maqui (Aristotelia chilensis), calafate (Berberis microphylla), Chilean strawberry (Fragaria chiloensis ssp. chiloensis), murta (Ugni molinae), and arrayan (Luma apiculata), and till date, murta and arrayan have been poorly studied. However, these berries have been used since ancient times as food, ingredients, colorants, and/or traditional medicines [4,5], and it opens the possibility of future scientific analysis 
in the fresh fruits and/or the development of studies for commercial exploitation through new processing technologies.

Specifically, murta and arrayan are two interesting and exotic berry fruits recognized as "superfruits," since these fruits present high levels in terms of fiber, vitamins, minerals, nutrients, and phytochemical composition [6]. Murta (also called murtilla, myrtle berry, or mutilla) is a wild Myrtaceae bush, with black/purple color and an intense sweet taste, and it grows from Talca $\left(35^{\circ} 25^{\prime} 36^{\prime \prime} \mathrm{S}, 71^{\circ} 40^{\prime} 18^{\prime \prime} \mathrm{W}\right.$, Maule Region, central Chile) to the Palena River ( $41^{\circ} 28^{\prime} 18^{\prime \prime}$ S, $72^{\circ} 56^{\prime} 12^{\prime \prime} \mathrm{W}$, Los Lagos Region, southern Chile) [7]. Similarly, arrayan (also called cauchao) is other wild Myrtaceae endemic plant that grows in forests from Valparaíso ( $33^{\circ} 03^{\prime} 47^{\prime \prime} \mathrm{S}, 71^{\circ} 38^{\prime} 22^{\prime \prime} \mathrm{W}$, Valparaiso Region, central Chile) to Aysen (45 $34^{\prime} 12^{\prime \prime}$ S, $72^{\circ} 03^{\prime} 58^{\prime \prime}$ W, Aysen del General Carlos Ibáñez del Campo region, southern Chile). The fruits have nearly globular shape with characteristic aroma [8]. Moreover, these fruits present an important content of phenolic compounds (phenolic acids, anthocyanins, flavonoids, flavonols, and tannins), and thus, it contributes significantly to the high value of antioxidant activity measured for these fruits [9-14]. Therefore, murta and arrayan have excellent potential to be incorporated into the diet for daily consumption, either as fresh fruits or derived products such as yogurt, jams, jellies, purees, and fruit juices [15].

Additionally, different innovations have been adopted in the food industry due to the demands of consumers, every day more interested and aware, for healthy, safe, tasty, and ideal functional foods with low impact on the environment [16]. Furthermore, these innovations can be made at any stage during the food processing, and in recent years, the changes have been observed through the implementation of emerging thermal and non-thermal technologies with the intention to increase the extraction of components, efficiency, percentage of recovery, stability, and preservation of nutritional and organoleptic characteristics in each food product [17-19].

Accordingly, freeze crystallization (FC) has attracted increasing attention as emerging non-thermal technology due to their important implications for the concentration of food solutions. Specifically, FC uses low temperatures to concentrate liquid solutions and it is based on the freezing of the water, and then, the unfrozen solution (cryoconcentrated) is separated from the ice crystals (frozen fraction). Thereby, FC allows increasing the solutes and bioactive compounds in the cryoconcentrated fraction. In turn, FC had a significant energy advantage compared to the traditional concentration technologies, since FC uses only $14 \%$ of the total energy used in evaporative concentration [20]. Hence, FC has been positively applied in various liquid foods, presenting an increase in solutes and extraordinary retention of phenolic compounds and antioxidant activity [21-25]. However, to our best knowledge, there are a few studies available about the application of FC on valuable "superfruit" juices [26,27].

Thus, the objective of this study was to evaluate the use of block FC assisted by centrifugation technology on two wild endemic Chilean berry juices (murta and arrayan) in terms of physicochemical properties, process parameters, and quality characteristics.

\section{Materials and Methods}

\subsection{Raw Materials}

Fresh murta (Ugni molinae) and arrayán (Luma apiculata) were obtained from Valle Exploradores Ltda ( $46^{\circ} 37^{\prime} 27^{\prime \prime}$ S, $72^{\circ} 40^{\prime} 36^{\prime \prime}$ W, Puerto Río Tranquilo, XI Región de Aysén, Chile), with standard commercial maturity, i.e., uniform size and color, and without visual damage (injured) or being immature. Thus, the samples were transported in covered insulated boxes at Chillán (XVI Región del Nuble, Chile) and were kept in a refrigerated chamber until their further analysis.

\subsection{Fruit Juice Preparation}

The fruits were washed with tap water to remove dust and dirt, and then subjected to manual pressure to obtain the juice, and then, the fresh juice was filtered using a nylon 
cloth (0.8 mm fine-mesh) to separate large fragments such as pulp, seeds, and peels from the liquid. Later, the fresh juice was stored at $4{ }^{\circ} \mathrm{C}$ until analysis or processing.

\subsection{Freeze Crystallization (FC)}

The FC process at three cycles was based on the protocol described by Orellana-Palma et al. [27] (Figure 1). First, the plastic centrifugal tubes with $45 \mathrm{~mL}$ of juice were isolated with foamed polystyrene. Then, the tubes with juice were frozen through axial freezing front propagation in a static freezer (model 280, M\&S Consul, Sao Paulo, Brazil) overnight at $-20{ }^{\circ} \mathrm{C}$. Later, the cryoconcentrated fraction was separated from the ice fraction by centrifugation (Eppendorf 5430R, Hamburg, Germany) at $20^{\circ} \mathrm{C}$ for $20 \mathrm{~min}$ at $4000 \mathrm{rpm}$, and thus, this procedure can be called the first cycle (C1). The cryoconcentrate juice obtained from $\mathrm{C} 1$ was collected. Subsequently, the $\mathrm{C} 1$ solution was used as the new feed solution for the second (C2) cycle, and thus, the $\mathrm{C} 2$ solution was used as new feed solution for the third (C3) cycle. All the cycles were performed under the same FC procedure (axial freezing front propagation at $-20^{\circ} \mathrm{C}$ and centrifugation conditions). Specifically, different quality properties such as physicochemical properties, total phenolic compound content, and antioxidant activity were determined in the cryoconcentrated fraction from $\mathrm{C} 1, \mathrm{C} 2$, and $\mathrm{C} 3$.

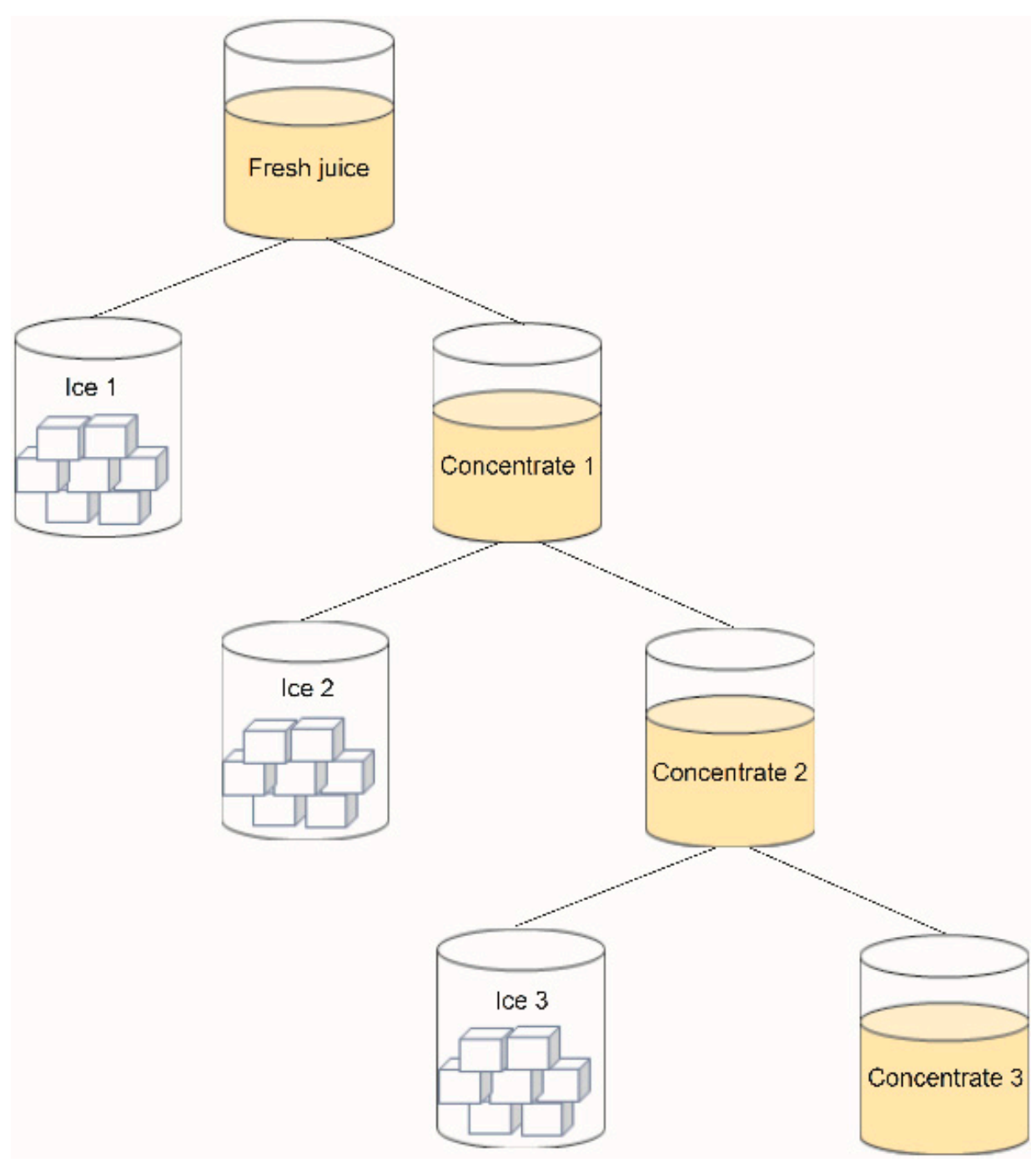

Figure 1. Freeze crystallization procedure at three centrifugation cycles. 


\subsection{Physicochemical Profile}

The physicochemical profile in the samples was measured based on the method described by Orellana-Palma et al. [27]. Thus, the TSS content was measured using a digital refractometer (PAL-3, Atago Inc., Tokyo, Japan) with wide range (0-93\%), and the results were expressed as Brix. The $\mathrm{pH}$ measurements were determined with a digital $\mathrm{pH}$ meter (HI-2221, Hanna Instruments, Woonsocket, RI, USA). The total titratable acidity (TTA) (grams of malic acid (MA) per liter of sample, g MA/L) was obtained by titrimetric method. The density $\left(\mathrm{kg} / \mathrm{m}^{3}\right)$ was obtained using a pycnometer at $25{ }^{\circ} \mathrm{C}$. The color properties were evaluated using a colorimeter (CM-5, Konica Minolta, Osaka, Japan), and the results were provided in accordance with CIELab system ( $L^{*}$ : darkness-whiteness, $\mathrm{a}^{*}$; greenness-redness axis, and $b^{*}$ : blueness-yellowness axis). The total color difference $\left(\Delta \mathrm{E}^{*}\right)$ was calculated in accordance with Equation (1).

$$
\Delta E^{*}=\sqrt{\left(L^{*}-L_{0}^{*}\right)^{2}+\left(a^{*}-a_{0}^{*}\right)^{2}+\left(b^{*}-b_{0}^{*}\right)^{2}},
$$

where $\Delta E^{*}$ is the change variation between fresh juices and cryoconcentrated samples. The subscript 0 corresponds to the initial CIELab values in the fresh juice, and $\mathrm{L}^{*}, \mathrm{a}^{*}$, and $\mathrm{b}^{*}$ are the color properties in each cryoconcentrated sample.

\subsection{Determination of Total Phenolic Compound Content (TPCC)}

TPCC were determined by the total polyphenol content (TPC), total anthocyanin content (TAC), and total flavonoid content (TFC) assays.

TPC, TAC, and TFC assays were measured with a spectrophotometer UV/Vis (T70, Oasis Scientific Inc., Greenville, SC, USA) based on the method described by Sekizawa et al. [28], Lee et al. [29], and Zhishen et al. [30], where gallic acid (GA), cyanidin-3-glucoside (C3G), and quercetin $(\mathrm{Q})$ were used for the standard curve, respectively, and the results were expressed in mg of GA equivalents (GAE) per grams (g) of dry matter (mg GAE/g d.m.), mg of C3G equivalents per grams (g) of dry matter (mg C3G/g d.m.), and $\mathrm{mg}$ of Q equivalents (QE) per grams (g) of dry matter (mg QE/g d.m.), respectively.

Additionally, the TPCC retention represents the TPCC retained from the fresh juice in the cryoconcentrated solution. The TPCC retention was determined by Equation (2) [31].

$$
\operatorname{TPCC} \text { retention }(\%)=\left(\frac{C_{\mathrm{o}}}{C_{\mathrm{c}}}\right) \times\left(\frac{T P C C_{\mathrm{c}}}{T P C C_{\mathrm{o}}}\right) \times 100 \text {, }
$$

where $\mathrm{C}_{\mathrm{o}}$ is the initial TSS; $\mathrm{C}_{\mathrm{c}}$ is the TSS at each cycle in the cryoconcentrated fraction; $\mathrm{TPCC}_{\mathrm{C}}$ is the value of TPC, TAC, and TFC at each cycle; and $\mathrm{TPCC}_{\mathrm{o}}$ is the initial value of TPC, TAC, and TFC.

\subsection{Determination of Antioxidant Activity (AA)}

Antioxidant activity was determined by means of the 2,2-diphenyl-1-picrylhydrazyl (DPPH), 2,2'-azino-bis(3-ethylbenzothiazoline-6-sulphonic acid) (ABTS), ferric reducing antioxidant power (FRAP), and oxygen radical absorbance capacity (ORAC) assays.

DPPH, ABTS, and FRAP assays were measured with a spectrophotometer UV/Vis (T70, Oasis Scientific Inc., Greenville, SC, USA) based on the method described by Zorzi et al. [32], Garzón et al. [33], and Chen et al. [34], respectively.

ORAC assay was evaluated based on the method described by Ou et al. [35] with a multimode plate reader (Victor X3, Perkin Elmer, Hamburg, Germany). The absorbance was measured at $485 \mathrm{~nm}\left(\lambda_{\text {excitation }}\right)$ and at $520 \mathrm{~nm}$ ( $\left.\lambda_{\text {emission }}\right)$ every $1 \mathrm{~min}$ for $60 \mathrm{~min}$.

Trolox (T) was used for the standard curve, and the AA assays were expressed as $\mu \mathrm{M}$ Trolox equivalents (TE) per gram (g) of dry matter ( $\mu \mathrm{M}$ TE/g d.m.). 


\subsection{Process Parameters in FC}

\subsubsection{Efficiency $(\eta)$}

$\eta(\%)$ is defined as the solutes in the cryoconcentrated fraction relative to the solutes remaining in the ice fraction. The $\eta(\%)$ was determined by Equation (3).

$$
\eta(\%)=\frac{C_{\mathrm{c}}-C_{\mathrm{I}}}{C_{\mathrm{c}}} * 100 \%,
$$

where $C_{c}$ and $C_{I}$ are the TSS at each cycle in the cryoconcentrated and ice fractions, respectively.

\subsubsection{Solute Yield (Y)}

$Y$ ( $\mathrm{kg}$ solutes $/ \mathrm{kg}$ initial solutes, $\mathrm{kg} / \mathrm{kg}$ ) represents the relation between the recovered solute mass in the initial solution and cryoconcentrated solution. The $Y(\mathrm{~kg} / \mathrm{kg})$ was determined by Equation (4).

$$
Y\left(\frac{\mathrm{kg}}{\mathrm{kg}}\right)=\frac{m_{\mathrm{c}}}{m_{0}},
$$

where $\mathrm{m}_{\mathrm{c}}$ is the solute mass in the cryoconcentrated fraction and $\mathrm{m}_{0}$ is the initial solute mass.

\subsubsection{Percentage of Concentrate (PC)}

PC (\%) represents the weight in the initial sample relative to the weight remaining in the ice fraction. The PC was determined by Equation (5).

$$
\operatorname{PC}(\%)=\frac{W_{0}-W_{\mathrm{i}}}{W_{0}} \times 100 \%,
$$

where $W_{0}$ and $W_{i}$ are the initial and final weights in the ice fraction, respectively.

\subsection{Statistical Analysis}

The treatments were conducted in triplicate at ambient temperature $\left(\approx 22^{\circ} \mathrm{C}\right)$, and the results were presented as mean \pm standard deviation. One-way analysis of variance (ANOVA) was used to the evaluation of statistical analysis and the treatment means were compared via Fisher's least significant difference (Fisher's LSD) test at a confidence level of $0.95(p \leq 0.05)$. The data were analyzed through Statgraphics Centurion XVI software (v. 16.2.04, StatPoint Technologies Inc., Warrenton, VA, USA).

\section{Results and Discussion}

\subsection{Physicochemical Characteristics}

The physicochemical properties in the fruit juices and CBFC-treated juices are shown in Figure 2 and Table 1. Additionally, the TSS, $\mathrm{pH}$, TTA, and color $\left(\mathrm{L}^{*}, \mathrm{a}^{*}, \mathrm{~b}^{*}\right.$ and $\left.\Delta \mathrm{E}^{*}\right)$ values presented significant differences when each BFC cycle was compared with their respective fresh juice.

The fresh murta juice presented lower physicochemical characteristics values than those indicated by Ah-Hen et al. [36]. However, our results were higher than previous results found in the same fruit juice by Ah-Hen et al. [37]. Moreover, the fresh arrayan juice values were higher than previous values reported by Fuentes et al. [13]. The differences can be connected to the fact that the studies were carried out with fruits from different areas of the Southern Chile, and these zones are characterized by various climatic conditions, equivalent to constant rains and low temperatures throughout the year [38]. Additionally, various factors such as type/time of harvesting, ripening process, and/or the interaction genotype-environment can change the properties of the fruit and juice [39]. 


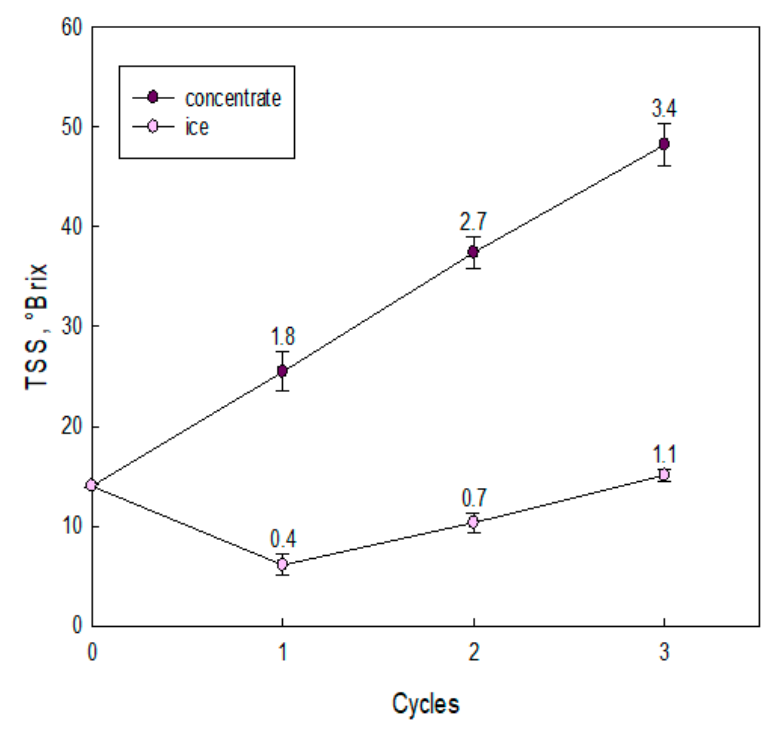

(a)

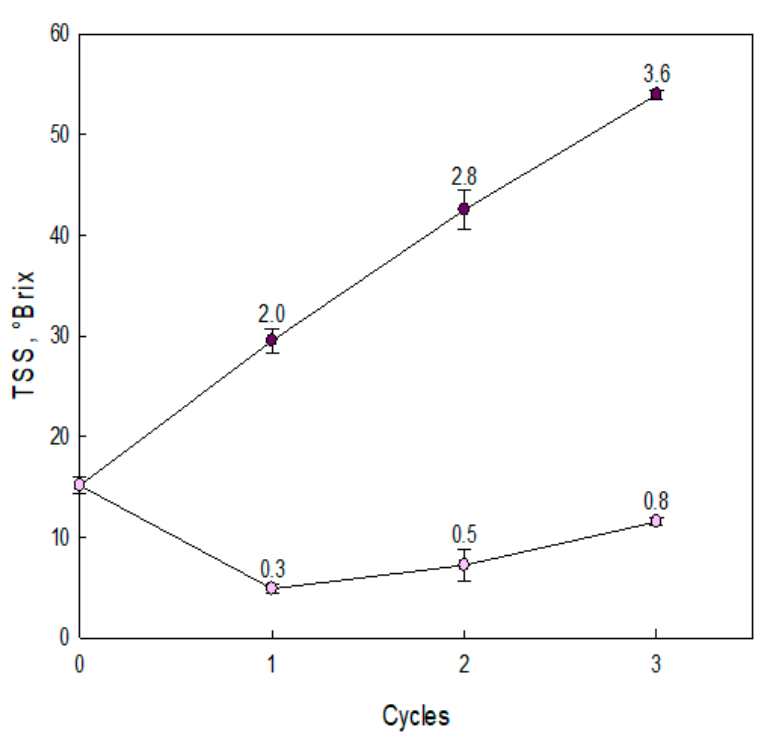

(b)

Figure 2. Total soluble solids (TSS) values at each BFC cycle: (a) murta juice and (b) arrayan juice. The bars represent the standard deviations. The number on the bar is the concentration index (CI), and $\mathrm{CI}$ is a dimensionless number that represents the increase in solutes at each BFC cycle (in both cryoconcentrated and ice fractions) with respect to the initial TSS value $\left(C_{0}\right)$ (14.0 Brix for murta juice and $15.1^{\circ}$ Brix for arrayan juice), i.e., $C I=C_{c} / C_{0}$, where $C_{c}$ is the TSS value at each cycle.

First, independent of fresh juice, the TSS values showed an increasing trend with increasing BFC cycles (Figure 2). Hence, in the last cycle, for murta juice (Figure 2a), the solutes reached a TSS value close to $48.2^{\circ}$ Brix, and for arrayan juice (Figure $2 \mathrm{~b}$ ), the TSS value was approximately $54.0^{\circ} \mathrm{Brix}$, which is comparable to an increase in 3.4 and 3.6 times, in relation to the initial TSS values (14.0 and $15.1^{\circ}$ Brix), respectively. In comparison with previous studies in our laboratory, the results (third cycle) presented lower concentration index value than those obtained in orange juice (5.7) [40] and apple juice (3.9) [41], but higher than those achieved in calafate juice (3.0) [27], pineapple juice (3.3) [42], and blueberry juice (2.5) [43]. The variation in TSS values is due to the different and specific characteristics ( $\mathrm{pH}, \mathrm{TTA}$, and density, among others) in the fresh juice, since each characteristic interacts under various forms in the cryoconcentration process [44]. It is worth to mention that, all the studies used the same freezing and centrifugation conditions.

The $\mathrm{pH}$, TTA, and CIELab $\left(\mathrm{L}^{*}, \mathrm{a}^{*}\right.$, and $\left.\mathrm{b}^{*}\right)$ values are given in Table 1 .

In terms of $\mathrm{pH}$, the values showed a significant decrease in both fresh murta juice $(\mathrm{pH}=3.7)$ and fresh arrayan juice $(\mathrm{pH}=5.1)$, since the values (third cycle) had a decrease in $27 \%(\mathrm{pH}=2.4)$ and $25 \%(\mathrm{pH}=3.8)$, in comparison to the correspondent $\mathrm{pH}$ value of the fresh juice, respectively. By contrast, the fresh murta juice and fresh arrayan juice increased the TTA values to 2.3 and 1.6 for $\mathrm{C} 1,3.1$ and 2.1 for $\mathrm{C} 2$, and 3.8 and 2.6 for $\mathrm{C} 3$, indicating an increase in $224 \%$ and $217 \%$ (in the last cycle) in relation to the initial TTA values, respectively. The opposite behavior among $\mathrm{pH}$ and TTA values has been observed in various cryoconcentrated food liquids such as calafate juice [27], pineapple juice [42], and sapucaia nut cake milk [45]. The $\mathrm{pH}$ and TTA changes have been attributed to the continuous increases in TSS at each cycle, since it provokes an increase in the organic acids of the cryoconcentrates, causing the opposite phenomenon between $\mathrm{pH}$ and TTA values [41].

In terms of colorimetric CIELab parameters, the color measurement is considered an indicator of food quality and can also be used indirectly in the analysis of colored components contained in fruits, particularly in berries, providing an estimation of antioxidants and polyphenolic compounds $[46,47]$. 
Table 1. Physicochemical characteristics of the samples.

\begin{tabular}{|c|c|c|c|c|c|c|c|c|c|c|c|c|}
\hline \multirow{2}{*}{ Sample } & \multicolumn{2}{|c|}{$\mathrm{pH}$} & \multicolumn{2}{|c|}{ TTA } & \multicolumn{2}{|c|}{$\mathbf{L}^{*}$} & \multicolumn{2}{|c|}{$a^{*}$} & \multicolumn{2}{|c|}{$\mathbf{b}^{*}$} & \multicolumn{2}{|c|}{$\Delta \mathrm{E}^{*}$} \\
\hline & Murta & Arrayan & Murta & Arrayan & Murta & Arrayan & Murta & Arrayan & Murta & Arrayan & Murta & Arrayan \\
\hline Fresh juice & $3.7 \pm 0.0^{a}$ & $5.1 \pm 0.1^{a}$ & $1.7 \pm 0.2^{a}$ & $1.2 \pm 0.0^{\mathrm{a}}$ & $51.9 \pm 1.4^{\mathrm{a}}$ & $12.2 \pm 0.1^{\mathrm{a}}$ & $3.8 \pm 0.8^{a}$ & $8.7 \pm 0.8^{a}$ & $2.6 \pm 0.5^{\mathrm{a}}$ & $1.1 \pm 0.2^{\mathrm{a}}$ & - & - \\
\hline Cycle 1 & $3.3 \pm 0.2^{b}$ & $4.7 \pm 0.2^{b}$ & $2.3 \pm 0.1^{b}$ & $1.6 \pm 0.2^{b}$ & $40.6 \pm 0.7^{b}$ & $7.5 \pm 0.5^{b}$ & $8.2 \pm 0.4^{\mathrm{b}}$ & $22.0 \pm 0.2^{b}$ & $5.9 \pm 0.1^{\mathrm{b}}$ & $14.0 \pm 0.2^{b}$ & $12.5 \pm 0.7^{\mathrm{a}}$ & $19.1 \pm 0.5^{\mathrm{a}}$ \\
\hline Cycle 2 & $2.8 \pm 0.1^{\mathrm{c}}$ & $4.2 \pm 0.2^{\mathrm{c}}$ & $3.1 \pm 0.4^{\mathrm{c}}$ & $2.1 \pm 0.1^{\mathrm{c}}$ & $28.2 \pm 0.4^{\mathrm{c}}$ & $4.1 \pm 0.2^{c}$ & $14.7 \pm 0.4^{\mathrm{c}}$ & $31.0 \pm 1.4^{\mathrm{c}}$ & $10.1 \pm 0.9^{c}$ & $22.6 \pm 1.3^{c}$ & $27.2 \pm 0.9^{b}$ & $32.0 \pm 1.1^{b}$ \\
\hline Cycle 3 & $2.4 \pm 0.1^{\mathrm{d}}$ & $3.8 \pm 0.0^{\mathrm{d}}$ & $3.8 \pm 0.2^{d}$ & $2.6 \pm 0.3^{d}$ & $14.4 \pm 1.4^{\mathrm{d}}$ & $0.4 \pm 0.5^{\mathrm{d}}$ & $34.9 \pm 0.3^{d}$ & $38.9 \pm 1.2^{d}$ & $15.1 \pm 0.9^{\mathrm{d}}$ & $33.4 \pm 0.4^{\mathrm{d}}$ & $50.3 \pm 1.2^{\mathrm{c}}$ & $45.7 \pm 0.7^{c}$ \\
\hline
\end{tabular}

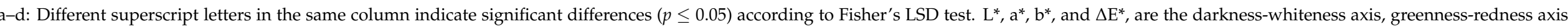
blueness-yellowness axis, and the total color difference, respectively. 
Thus, all the samples presented an important change during the cycles, since each parameter had significant modifications, and thus, in $\mathrm{C} 3$, the $\mathrm{L}^{*}$ values decrease from 52 to 14 CIELab units and from 12 to 0.4 CIELab units, for fresh murta and arrayan juices, which is equivalent to a decrease in $72 \%$ and $96 \%$, respectively, signifying that the cryoconcentrated samples were darker than the original juice. However, as cycles advanced, a progressive increase in $\mathrm{a}^{*}$ and $\mathrm{b}^{*}$ values was observed, with values from 4 to 35 CIELab units and from 3 to 15 CIELab units, for murta juice, and from 9 to 39 CIELab units and from 1 to 33 CIELab units, for arrayan juice, respectively, indicating that the juices had a darkish red color (most noticeable in arrayan juice), and thus, the final cryoconcentrated samples presented a very dark visual appearance with red coloration (Figure 3). These results suggested that the changes in visual color of fresh juices treated by BFC can be linked to the notable increase in the TSS concentration and total phenolic compound content at each cycle [48]. Additionally, the $\Delta \mathrm{E}^{*}$ between the samples (fruit juices and CBFC-treated juices) specified that the highest $\Delta \mathrm{E}^{*}$ values were assessed for the final cycle, since the values ranged from 13 to 50 CIELab units and from 19 to 46 CIELab units, from the first to the third cycle, for murta juice and for arrayan juice, respectively. Specifically, Krapfenbauer et al. [49] defined that a $\Delta \mathrm{E}^{*} \geq 3.5$ CIELab units denote visual differences by the consumers between food products. Therefore, our values indicate that the human eye can perceive visual differences between the original sample and each cryoconcentrated sample, since all the $\Delta \mathrm{E}^{*}$ values were higher than 13 CIELab units. All the data and visual color had similar trend to the results reported in various studies on FC applied to fresh juices [27,31,43].

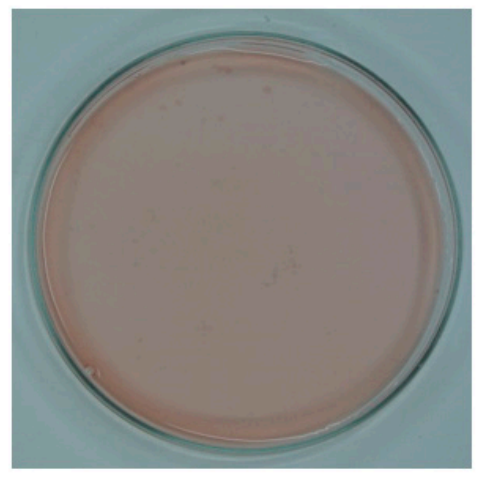

(a)

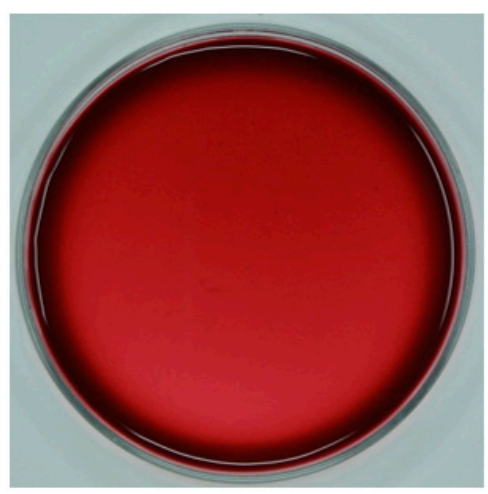

(c)

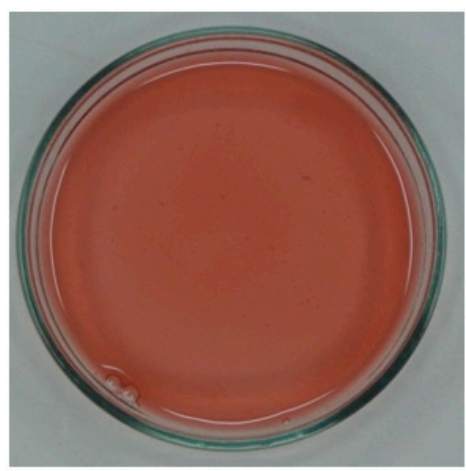

(b)

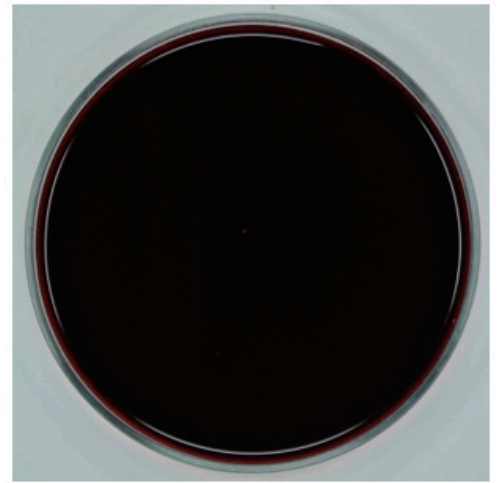

(d)

Figure 3. Effect on visual color of fresh murta juice and fresh arrayan juice under centrifugal block freeze crystallization (CBFC): (a) fresh murta juice, (b) cryoconcentrated murta juice, (c) fresh arrayan juice, and (d) cryoconcentrated arrayan juice.

\subsection{Total Phenolic Compound Content (TPCC)}

The levels of TPCC in the fruit juices and CBFC-treated juices are shown in Table 2. 
Table 2. Total phenolic compound content of fresh juices and cryoconcentrated samples.

\begin{tabular}{|c|c|c|c|c|c|c|}
\hline \multirow[t]{2}{*}{ Sample } & \multicolumn{2}{|c|}{$\begin{array}{c}\text { TPC } \\
\text { (mg GAE/g d.m.) }\end{array}$} & \multicolumn{2}{|c|}{$\begin{array}{c}\text { TAC } \\
\text { (mg C3G/g d.m.) }\end{array}$} & \multicolumn{2}{|c|}{$\begin{array}{c}\text { TFC } \\
\text { (mg QE/g d.m.) }\end{array}$} \\
\hline & Murta & Arrayan & Murta & Arrayan & Murta & Arrayan \\
\hline Fresh juice & $6.4 \pm 0.8^{a}$ & $20.5 \pm 2.1^{a}$ & $4.2 \pm 0.1^{\mathrm{a}}$ & $8.2 \pm 0.9^{a}$ & $3.2 \pm 0.0^{\mathrm{a}}$ & $6.0 \pm 0.2^{a}$ \\
\hline Cycle 1 & $8.1 \pm 0.2^{b}$ & $28.7 \pm 1.1^{\mathrm{b}}$ & $5.1 \pm 0.9^{b}$ & $10.5 \pm 0.5^{b}$ & $3.6 \pm 0.1^{b}$ & $6.9 \pm 0.2^{b}$ \\
\hline TPCC retention (\%) & $70.0 \pm 2.1^{\mathrm{A}}$ & $76.9 \pm 0.5^{\mathrm{A}}$ & $66.6 \pm 1.0^{\mathrm{A}}$ & $70.8 \pm 0.6^{\mathrm{A}}$ & $62.1 \pm 0.9^{\mathrm{A}}$ & $63.2 \pm 0.1^{\mathrm{A}}$ \\
\hline Cycle 2 & $13.4 \pm 1.0^{\mathrm{c}}$ & $47.0 \pm 2.9^{c}$ & $8.3 \pm 1.3^{c}$ & $17.0 \pm 2.0^{c}$ & $5.8 \pm 0.4^{\mathrm{c}}$ & $11.4 \pm 1.4^{\mathrm{c}}$ \\
\hline TPCC retention (\%) & $78.6 \pm 0.9^{\mathrm{B}}$ & $85.9 \pm 1.2^{\mathrm{B}}$ & $73.1 \pm 1.4^{\mathrm{B}}$ & $77.9 \pm 1.1^{\mathrm{B}}$ & $67.8 \pm 1.3^{\mathrm{B}}$ & $71.1 \pm 2.9^{B}$ \\
\hline Cycle 3 & $19.9 \pm 1.2^{d}$ & $65.6 \pm 3.8^{d}$ & $12.5 \pm 1.7^{\mathrm{d}}$ & $24.8 \pm 1.7^{\mathrm{d}}$ & $8.6 \pm 0.9^{d}$ & $17.0 \pm 2.3^{d}$ \\
\hline TPCC retention (\%) & $91.1 \pm 1.5^{\mathrm{C}}$ & $93.1 \pm 0.2^{C}$ & $85.6 \pm 2.0^{C}$ & $88.0 \pm 0.7^{C}$ & $78.1 \pm 2.4^{C}$ & $82.5 \pm 1.2^{C}$ \\
\hline
\end{tabular}

a-d: Different small letters in the same column indicate significant differences $(p<0.05)$ between the fresh juice and their cycles, according to Fisher's LSD test. A-D: Different capital letters in the same column indicate significant differences $(p \leq 0.05)$ between the TPCC retention at each cycle, according to Fisher's LSD test. TPCC, TPC, TAC, and TFC, are the total phenolic compound content, total polyphenol content, total anthocyanin content, and total flavonoid content, respectively.

First, fresh murta juice had TPCC values close to $6.4 \mathrm{mg}$ GAE/g d.m., $4.2 \mathrm{mg} \mathrm{C3G/g}$ d.m., and $3.2 \mathrm{mg}$ QE/g d.m., while fresh arrayan juice had TPCC values of approximately $20.5 \mathrm{mg} \mathrm{GAE} / \mathrm{g}$ d.m., $8.2 \mathrm{mg} \mathrm{C} 3 \mathrm{G} / \mathrm{g} \mathrm{d}$.m., and $6.0 \mathrm{mg} \mathrm{QE} / \mathrm{g}$ d.m., for TPC, TAC, and TAC, respectively. These results were lower than the ones reported by Ramirez [50], who reported the phenolic compounds content profile of six small berries from the VIII Region del Bio-Bío of Chile. However, the differences in TBCC values between the studies might be explained by the different harvest areas, since the VIII Region del Bio-Bío has dry temperate climates in summer and rainy temperate climates in winter, and thus, the temperature varies from 0 to $30^{\circ} \mathrm{C}$ throughout the year, while the Southern Chile has constant rains and low temperatures throughout the year $[38,51,52]$. Hence, the climatic conditions and geographical characteristics contribute to various differences on fruit maturation, and in addition, other factors such as genetic and species variabilities, harvesting year, and growing season affect the phenolic compounds content in final fruits [53].

Concerning TPCC results, a similar behavior to the TSS values was observed, since a significant increase in TPC, TAC, and TFC values was detected as cycles advanced. Thus, in the last cycle, for murta juice, the values were close to $20.0 \mathrm{mg}$ GAE/g d.m., $12.5 \mathrm{mg}$ $\mathrm{C} 3 \mathrm{G} / \mathrm{g}$ d.m., and $8.6 \mathrm{mg} \mathrm{QE} / \mathrm{g}$ d.m., and for arrayan juice, the values were approximately $65.6 \mathrm{mg}$ GAE/g d.m., $24.8 \mathrm{mg} \mathrm{C} 3 \mathrm{G} / \mathrm{g}$ d.m., and $17.0 \mathrm{mg} \mathrm{QE} / \mathrm{g}$ d.m., for the first, second, and third cycle, respectively, and thus, these values were over 2.7 times higher than the correspondent initial TPCC value. This upward trend in TPCC values post-FC has been observed in numerous food liquids such as green tea extract [21], fruit juices [22-24], broccoli extract [25], coffee extract [54], and wine [55]. Additionally, the retention specified a high amount of TPCC in the cryoconcentrated fraction, since the retention values (third cycle) were close to $91 \%, 86 \%$, and $78 \%$, for murta juice, and $93 \%, 88 \%$, and $82 \%$, for arrayan juice, for TPC, TAC, and TFC, respectively. The results were consistent with the values informed by Orellana-Palma et al. [41], Casas-Forero et al. [31], and Correa et al. [56], who reported TPCC retention close to $85 \%, 71-91 \%$, and $90 \%$, in apple juice, blueberry juice, and coffee extract, respectively. Therefore, the TPCC value and retention results allow corroborating that the FC technology can be visualized as a novel alternative due to the low temperatures used to concentrate, preserve, and retain an endless number of phenolic components such as polyphenols, anthocyanins, and flavonoids in the cryoconcentrated fraction [20].

\subsection{Antioxidant Activity (AA)}

Table 3 shows the AA values of the samples. 
Table 3. Antioxidant activity ( $\mu \mathrm{M}$ TE/g d.m.) of fresh juices and cryoconcentrated samples.

\begin{tabular}{|c|c|c|c|c|c|c|c|c|}
\hline \multirow{2}{*}{ Sample } & \multicolumn{2}{|c|}{ DPPH } & \multicolumn{2}{|c|}{ ABTS } & \multicolumn{2}{|c|}{ FRAP } & \multicolumn{2}{|c|}{ ORAC } \\
\hline & Murta & Arrayan & Murta & Arrayan & Murta & Arrayan & Murta & Arrayan \\
\hline Fresh juice & $33.4 \pm 3.7^{\mathrm{a}}$ & $62.0 \pm 7.4^{\mathrm{a}}$ & $48.1 \pm 7.6^{a}$ & $84.8 \pm 9.9^{a}$ & $62.6 \pm 5.9^{a}$ & $92.6 \pm 3.1^{a}$ & $21.7 \pm 3.0^{\mathrm{a}}$ & $43.4 \pm 4.4^{\mathrm{a}}$ \\
\hline Cycle 1 & $96.9 \pm 10.1^{b}$ & $167.3 \pm 11.6^{b}$ & $110.6 \pm 19.1^{b}$ & $229.0 \pm 10.4^{b}$ & $156.5 \pm 15.7^{b}$ & $287.0 \pm 17.2^{b}$ & $45.6 \pm 7.4^{b}$ & $99.8 \pm 11.7^{b}$ \\
\hline Cycle 2 & $120.2 \pm 8.5^{c}$ & $266.4 \pm 20.3^{c}$ & $187.6 \pm 10.7^{c}$ & $373.1 \pm 20.5^{c}$ & $256.7 \pm 13.9^{c}$ & $416.6 \pm 20.7^{c}$ & $80.3 \pm 5.9^{c}$ & $204.0 \pm 17.0^{c}$ \\
\hline Cycle 3 & $157.0 \pm 12.3^{d}$ & $353.1 \pm 14.0^{\mathrm{d}}$ & $250.1 \pm 17.2^{d}$ & $407.0 \pm 7.6^{\mathrm{d}}$ & $338.0 \pm 21.4^{\mathrm{d}}$ & $509.1 \pm 23.1^{\mathrm{d}}$ & $108.5 \pm 10.1^{d}$ & $221.3 \pm 20.5^{\mathrm{d}}$ \\
\hline
\end{tabular}

a-d: Different superscript letters in the same column indicate significant differences ( $p \leq 0.05)$ according to Fisher's LSD test.

First, in both murta and arrayan juices, the AA values ( $\mu \mathrm{M}$ TE/g d.m.) were approximately 33.4, 48.1, 62.6, and 21.7, and 62.0, 84.8, 92.6, and 43.4, for DPPH, ABTS, FRAP, and ORAC, respectively. These values were lower than those found by Ramirez et al. [48], Augusto et al. [57], and Rodríguez et al. [58], who studied some quality properties of native berries species from different regions of Chile, explicating that the high variability in AA values can be justified by the interaction of factors such as edaphoclimatic conditions (climate, light, temperature, and other conditions), geographical zone, cultivar/genotype, harvesting period, cultivation practice, fruit maturation, type of storage, and even, the type of juice extraction from the fruit [59].

Once the fruit juices were subjected to three CBFC cycles, an important increase in the AA values ( $\mu \mathrm{M}$ TE/g d.m.) was detected, with AA values from 96.9 to 157.0 and from 167.3 to 353.1, for DPPH, from 110.6 to 250.1 and from 229.0 to 407.0 , for ABTS, from 156.5 to 338.0 and from 287.0 to 590.1, for FRAP, and from 45.6 to 108.5 and from 99.8 to 221.3, for ORAC, from the $\mathrm{C} 1$ to $\mathrm{C} 3$, for murta juice, and for arrayan juice, which is equivalent to an increase over 2.1, 2.5, 2.7, and 2.8 times, in comparison to the AA values from the fresh juices, respectively. In this way, Orellana-Palma et al. [27], Samsuri et al. [60], and Casas-Forero et al. [61] also observed higher AA values post-FC than the original sample, demonstrating the positive effects of the FC on TPCC, and in turn, these components allow concentrating and preserving the antioxidant activity from the fresh juice [21].

\subsection{Process Parameters}

The $\eta, P C$, and Y results at each cycle are presented on Figure 4.

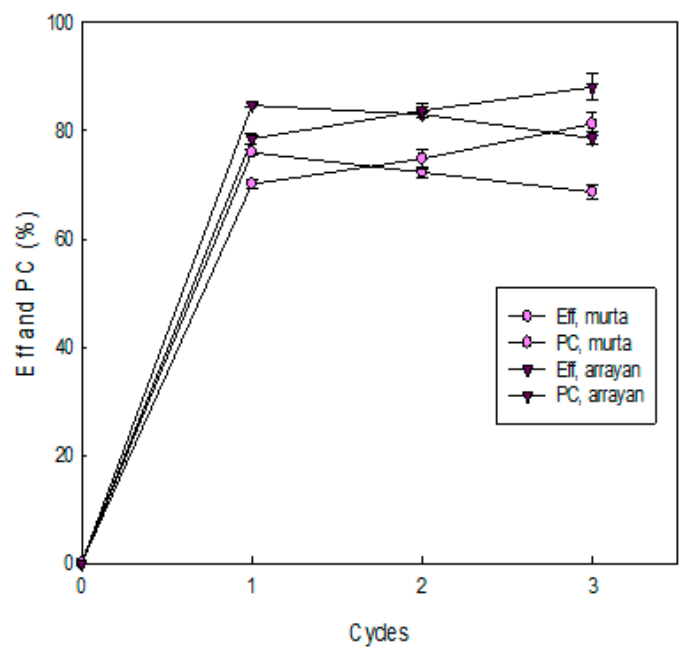

(a)

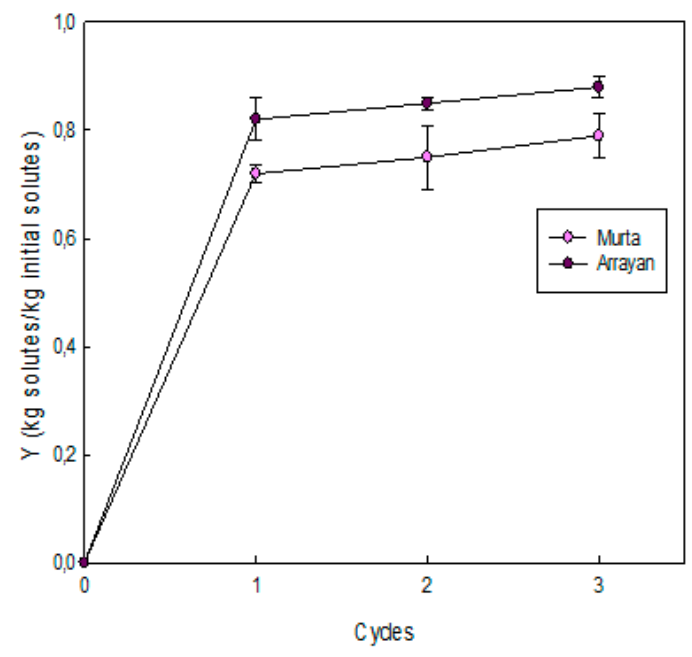

(b)

Figure 4. Process parameters at each CBFC cycle: (a) efficiency and percentage of concentrate and (b) solute yield.

The $\eta$ (Figure 4a) showed a significant decreasing trend from $\mathrm{C} 1$ to $\mathrm{C} 3$, with values close to $76 \%, 72 \%$, and $69 \%$, and $85 \%, 83 \%$, and $79 \%$, for murta juice and for arrayan juice, respectively. The results have similar ranges established by Bastías-Montes et al. [26], Orellana-Palma et al. [41], and Zielinski et al. [62], who studied the effect of FC in various 
liquid samples, specifying that the $\eta$ can be related to the TSS values. Specifically, the decrease in $\eta$ values can be related to the continuous increase in TSS values in the feed solution at each cycle, since the viscosity increases as the solutes increase, and thus, the flow of solutes was slowed in the third cycle than in the previous cycles, causing a difficulty in the separation process. In addition, the high viscosity reduces the ice purity postcentrifugation (increase in TSS values in the ice fractions cycle to cycle) [43].

The PC (Figure 4a) displayed an increasing tendency as the cycles passed, with values from $70 \%$ to $81 \%$, for murta juice, and from $78 \%$ to $88 \%$, for arrayan juice, from the $\mathrm{C} 1$ to C3, respectively. The values were similar to those reported in other samples $[22,40,62]$, suggesting that the PC values can be connected to the components in the fresh juice, since each juice has multiple components that interact differently in the FC process, and later, in the separation process, these components can facilitate or complicate the extraction of cryoconcentrates from the ice fraction [63].

The $\mathrm{Y}$ parameter (Figure $4 \mathrm{~b}$ ) showed a significant increasing trend as the cycles advanced, with values of approximately $0.72,0.75$, and 0.79 ( $\mathrm{kg}$ solutes $/ \mathrm{kg}$ initial solutes), for murta juice, and $0.82,0.85$, and 0.88 ( $\mathrm{kg}$ solutes $/ \mathrm{kg}$ initial solutes), for arrayan juice, for the $\mathrm{C} 1, \mathrm{C} 2$, and $\mathrm{C} 3$, respectively. The results had comparable performance that prior studies [40,41,62], associating the $Y$ values with the recovered mass from the original mass, i.e., for each applied cycle, a high quantity of mass can be extracted and collected as a cryoconcentrated sample [64].

\section{Conclusions}

The application of CBFC allowed obtaining higher solutes than the original sample, with an intensification of the natural color of the fresh juices, leading to increase in the phenolic compounds and antioxidant capacity in the cryoconcentrates samples, since the TPCC and AA results were over 2.7 and 2.1 times higher than the correspondent initial values, respectively. Moreover, the centrifugation improves the possibility to efficiently extract more cryoconcentrate from the ice fraction due to the high values in $\eta, P C$, and Y. These data suggest that FC can effectively improve the quality properties as well as visual appearance in any fruit juices. Thereby, the FC creates a unique opportunity for food industry, since this novel emerging non-thermal technology concentrates at low temperatures, and thus, various characteristics from the fresh juice can be retained in the final concentrated product. Therefore, the next challenge could be linked to FC in the production of concentrated juice rich in phenolic components and high antioxidant capacity from endemic fruits at pilot plant scale, and then at industrial scale, and in addition, the cryoconcentrated samples could be studied with a nutritional perspective.

Author Contributions: Conceptualization, M.G.-V., S.L.-P., P.O.-P., and G.P.; methodology, M.G.-V., S.L.-P., and P.O.-P.; software, M.G.-V., S.L.-P., and P.O.-P.; validation, M.G.-V. and S.L.-P.; formal analysis, M.G.-V., P.O.-P., and G.P.; investigation, M.G.-V., S.L.-P., and P.O.-P.; resources, P.O.-P. and G.P.; data curation, M.G.-V. and S.L.-P.; writing—original draft preparation, M.G.-V., S.L.-P., and P.O.-P.; writing—review and editing, P.O.-P. and G.P.; visualization, P.O.-P. and G.P.; supervision, P.O.-P. and G.P.; project administration, P.O.-P.; funding acquisition, P.O.-P. All authors have read and agreed to the published version of the manuscript.

Funding: This research was supported by ANID-Chile (Agencia Nacional de Investigación y Desarrollo de Chile) through the FONDECYT Postdoctoral Grant 2019 (Folio 3190420).

Institutional Review Board Statement: Not applicable.

Informed Consent Statement: Not applicable.

Data Availability Statement: Not applicable.

Acknowledgments: P.O.-P. acknowledges the financial support of ANID-Chile (Agencia Nacional de Investigación y Desarrollo de Chile) through the FONDECYT Postdoctoral Grant 2019 (Folio 3190420). M.G.-V. thanks at the Universidad del Bío-Bío for the doctoral scholarship (2018-2022) and for the "Beca de Investigación." 
Conflicts of Interest: The authors declare no conflict of interest.

\section{References}

1. Lavefve, L.; Howard, L.R.; Carbonero, F. Berry polyphenols metabolism and impact on human gut microbiota and health. Food Funct. 2020, 11, 45-65. [CrossRef] [PubMed]

2. Martini, D.; Marino, M.; Angelino, D.; del Bo', C.; del Rio, D.; Riso, P.; Porrini, M. Role of berries in vascular function: A systematic review of human intervention studies. Nutr. Rev. 2020, 78, 189-206. [CrossRef] [PubMed]

3. Vega-Galvez, A.; Rodríguez, A.; Stucken, K. Antioxidant, functional properties and health-promoting potential of native South American berries: A review. J. Sci. Food Agric. 2021, 101, 364-378. [CrossRef]

4. Schmeda-Hirschmann, G.; Jiménez-Aspee, F.; Theoduloz, C.; Ladio, A. Patagonian berries as native food and medicine. J. Ethnopharmacol. 2019, 241, 111979. [CrossRef]

5. Boeri, P.; Piñuel, L.; Dalzotto, D.; Monasterio, R.; Fontana, A.; Sharry, S.; Barrio, D.A.; Carrillo, W. Argentine Patagonia barberry chemical composition and evaluation of its antioxidant capacity. J. Food Biochem. 2020, 44, e13254. [CrossRef]

6. Chang, S.K.; Alasalvar, C.; Shahidi, F. Superfruits: Phytochemicals, antioxidant efficacies, and health effects-A comprehensive review. Crit. Rev. Food Sci. 2019, 59, 1580-1604. [CrossRef]

7. Fredes, C.; Parada, A.; Salinas, J.; Robert, P. Phytochemicals and traditional use of two southernmost Chilean berry fruits: Murta (Ugni molinae Turcz) and Calafate (Berberis buxifolia Lam.). Foods 2020, 9, 54. [CrossRef] [PubMed]

8. Carhuapoma, M.; Bonilla, P.; Suarez, S.; Villa, R.; López, S. Estudio de la composición química y actividad antioxidante del aceite esencial de Luma chequen (Molina) A. Gray "arrayán". Ciencia e Investigación 2005, 8, 73-79. [CrossRef]

9. López, J.; Vera, C.; Bustos, R.; Florez-Mendez, J. Native berries of Chile: A comprehensive review on nutritional aspects, functional properties, and potential health benefits. J. Food Meas. Charact 2020, in press. [CrossRef]

10. Viktorová, J.; Kumar, R.; Řehořová, K.; Hoang, L.; Ruml, T.; Figueroa, C.R.; Valdenegro, M.; Fuentes, L. antimicrobial activity of extracts of two native fruits of Chile: Arrayan (Luma apiculata) and Peumo (Cryptocarya alba). Antibiotics 2020, 9, 444. [CrossRef]

11. Junqueira-Gonçalves, M.P.; Yáñez, L.; Morales, C.; Navarro, M.; Contreras, R.; Zúñiga, G.E. Isolation and characterization of phenolic compounds and anthocyanins from Murta (Ugni molinae Turcz.) fruits. Assessment of antioxidant and antibacterial activity. Molecules 2015, 20, 5698-5713. [CrossRef]

12. Jofré, I.; Pezoa, C.; Cuevas, M.; Scheuermann, E.; Freires, I.A.; Rosalen, P.L.; de Alencar, S.M.; Romero, F. Antioxidant and vasodilator activity of Ugni molinae Turcz. (murtilla) and its modulatory mechanism in hypotensive response. Oxid. Med. Cell. Longev. 2016, 2016, 6513416. [CrossRef]

13. Fuentes, L.; Valdenegro, M.; Gómez, M.G.; Ayala-Raso, A.; Quiroga, E.; Martínez, J.P.; Vinet, R.; Caballero, E.; Figueroa, C.R. Characterization of fruit development and potential health benefits of arrayan (Luma apiculata), a native berry of South America. Food Chem. 2016, 196, 1239-1247. [CrossRef] [PubMed]

14. Fuentes, L.; Figueroa, C.R.; Valdenegro, M.; Vinet, R. Patagonian berries: Healthy potential and the path to becoming functional foods. Foods 2019, 8, 289. [CrossRef]

15. Pires, T.C.; Caleja, C.; Santos-Buelga, C.; Barros, L.; Ferreira, I.C. Vaccinium myrtillus L. fruits as a novel source of phenolic compounds with health benefits and industrial applications-a review. Curr. Pharm. Des. 2020, 26, 1917-1928. [CrossRef] [PubMed]

16. Martins, I.B.A.; Rosenthal, A.; Ares, G.; Deliza, R. How do processing technology and formulation influence consumers' choice of fruit juice? Int. J. Food Sci. Tech. 2020, 55, 2660-2668. [CrossRef]

17. Meijer, G.W.; Lähteenmäki, L.; Stadler, R.H.; Weiss, J. Issues surrounding consumer trust and acceptance of existing and emerging food processing technologies. Crit. Rev. Food Sci. Nutr. 2021, 61, 97-115. [CrossRef] [PubMed]

18. Wen, L.; Zhang, Z.; Sun, D.W.; Sivagnanam, S.P.; Tiwari, B.K. Combination of emerging technologies for the extraction of bioactive compounds. Crit. Rev. Food Sci. Nutr. 2020, 60, 1826-1841. [CrossRef] [PubMed]

19. Siegrist, M.; Hartmann, C. Consumer acceptance of novel food technologies. Nat. Food 2020, 1, 343-350. [CrossRef]

20. Miyawaki, O.; Inakuma, T. Development of progressive freeze concentration and its application: A review. Food Bioproc Tech. 2021, 14, 39-51. [CrossRef]

21. Meneses, D.L.; Ruiz, Y.; Hernandez, E.; Moreno, F.L. Multi-stage block freeze-concentration of green tea (Camellia sinensis) extract. J. Food Eng. 2021, 293, 110381. [CrossRef]

22. Orellana-Palma, P.; Petzold, G.; Guerra-Valle, M.; Astudillo-Lagos, M. Impact of block cryoconcentration on polyphenol retention in blueberry juice. Food Biosci. 2017, 20, 149-158. [CrossRef]

23. Qin, F.G.; Ding, Z.; Peng, K.; Yuan, J.; Huang, S.; Jiang, R.; Shao, Y. Freeze concentration of apple juice followed by centrifugation of ice packed bed. J. Food Eng. 2021, 291, 110270. [CrossRef]

24. Das, D.; Das, D.; Gupta, A.K.; Mishra, P. Drying of citrus grandis (pomelo) fruit juice using block freeze concentration and spray drying. Acta Aliment. 2020, 49, 295-306. [CrossRef]

25. Azhar, A.N.; Panirselvam, M.; Amran, N.A.; Ruslan, M.S.; Samsuri, S. Retention of total phenolic content and antioxidant activity in the concentration of broccoli extract by progressive freeze concentration. Int. J. Food Eng. 2020, 16, 20190237. [CrossRef]

26. Bastías-Montes, J.M.; Martín, V.S.; Muñoz-Fariña, O.; Petzold-Maldonado, G.; Quevedo-León, R.; Wang, H.; Yang, Y.; Céspedes-Acuña, C.L. Cryoconcentration procedure for aqueous extracts of maqui fruits prepared by centrifugation and filtration from fruits harvested in different years from the same localities. J. Berry Res. 2019, 9, 377-394. [CrossRef] 
27. Orellana-Palma, P.; Tobar-Bolaños, G.; Casas-Forero, N.; Zúñiga, R.N.; Petzold, G. Quality attributes of cryoconcentrated calafate (Berberis microphylla) juice during refrigerated storage. Foods 2020, 9, 1314. [CrossRef] [PubMed]

28. Sekizawa, H.; Ikuta, K.; Mizuta, K.; Takechi, S.; Suzutani, T. Relationship between polyphenol content and anti-influenza viral effects of berries. J. Sci. Food Agric. 2013, 93, 2239-2241. [CrossRef] [PubMed]

29. Lee, J.; Durst, R.W.; Wrolstad, R.E. Determination of total monomeric anthocyanin pigment content of fruit juices, beverages, natural colorants, and wines by the $\mathrm{pH}$ differential method: Collaborative study. J. AOAC Int. 2005, 88, 1269-1278. [CrossRef]

30. Zhishen, J.; Mengcheng, T.; Jianming, W. The determination of flavonoid contents in mulberry and their scavenging effects on superoxide radicals. Food Chem. 1999, 64, 555-559. [CrossRef]

31. Casas-Forero, N.; Orellana-Palma, P.; Petzold, G. Influence of block freeze concentration and evaporation on physicochemical properties, bioactive compounds and antioxidant activity in blueberry juice. Food Sci. Technol. 2020, 40, 387-394. [CrossRef]

32. Zorzi, M.; Gai, F.; Medana, C.; Aigotti, R.; Morello, S.; Peiretti, P.G. Bioactive compounds and antioxidant capacity of small berries. Foods 2020, 9, 623. [CrossRef]

33. Garzón, G.A.; Riedl, K.M.; Schwartz, S.J. Determination of anthocyanins, total phenolic content, and antioxidant activity in Andes berry (Rubus glaucus Benth). J. Food Sci. 2009, 74, C227-C232. [CrossRef] [PubMed]

34. Chen, L.; Xin, X.; Yuan, Q.; Su, D.; Liu, W. Phytochemical properties and antioxidant capacities of various colored berries. J. Sci. Food Agric. 2014, 94, 180-188. [CrossRef] [PubMed]

35. Ou, B.; Hampsch, M.; Prior, R.L. Development and validation of an improved oxygen radical absorbance capacity assay using fluorescein as the fluorescent probe. J. Agric. Food Chem. 2001, 49, 4619-4626. [CrossRef]

36. Ah-Hen, K.; Zambra, C.E.; Aguëro, J.E.; Vega-Gálvez, A.; Lemus-Mondaca, R. Moisture diffusivity coefficient and convective drying modelling of murta (Ugni molinae Turcz): Influence of temperature and vacuum on drying kinetics. Food Bioprocess Technol. 2013, 6, 919-930. [CrossRef]

37. Ah-Hen, K.S.; Mathias-Rettig, K.; Gómez-Pérez, L.S.; Riquelme-Asenjo, G.; Lemus-Mondaca, R.; Muñoz-Fariña, O. Bioaccessibility of bioactive compounds and antioxidant activity in murta (Ugni molinae T.) berries juices. J. Food Meas. Charact. 2018, 12, 602-615. [CrossRef]

38. Aceituno, P.; Boisier, J.P.; Garreaud, R.; Rondanelli, R.; Rutllant, J.A. Climate and Weather in Chile. In Water Resources of Chile, 2nd ed.; Fernández, B., Gironás, J., Eds.; Springer: Cham, Switzerland, 2020; pp. 7-29.

39. Cheng, G.; He, Y.N.; Yue, T.X.; Wang, J.; Zhang, Z.W. Effects of climatic conditions and soil properties on Cabernet Sauvignon berry growth and anthocyanin profiles. Molecules 2014, 19, 13683-13703. [CrossRef] [PubMed]

40. Orellana-Palma, P.; González, Y.; Petzold, G. Improvement of centrifugal cryoconcentration by ice recovery applied to orange juice. Chem. Eng. Technol. 2019, 42, 925-931. [CrossRef]

41. Orellana-Palma, P.; Lazo-Mercado, V.; Gianelli, M.P.; Hernández, E.; Zuñiga, R.; Petzold, G. Influence of cryoconcentration on quality attributes of apple juice (Malus domestica cv. Red Fuji). Appl. Sci. 2020, 10, 959. [CrossRef]

42. Orellana-Palma, P.; Zuñiga, R.N.; Takhar, P.S.; Gianelli, M.P.; Petzold, G. Effects of centrifugal block freeze crystallization on quality properties in pineapple juice. Chem. Eng. Technol. 2020, 43, 355-364. [CrossRef]

43. Petzold, G.; Moreno, J.; Lastra, P.; Rojas, K.; Orellana, P. Block freeze concentration assisted by centrifugation applied to blueberry and pineapple juices. Innov. Food Sci. Emerg. 2015, 30, 192-197. [CrossRef]

44. Ho, K.K.; Ferruzzi, M.G.; Wightman, J.D. Potential health benefits of (poly)phenols derived from fruit and 100\% fruit juice. Nutr Rev. 2020, 78, 145-174. [CrossRef] [PubMed]

45. Demoliner, F.; de Carvalho, L.T.; de Liz, G.R.; Prudêncio, E.S.; Ramos, J.C.; Bascuñan, V.L.A.F.; Vitali, L; Block, J.M. Improving the nutritional and phytochemical compounds of a plant-based milk of sapucaia nut cake using block freeze concentration. Int. J. Food Sci. Technol. 2020, 55, 3031-3042. [CrossRef]

46. Romero-Román, M.E.; Schoebitz, M.; Bastías, R.M.; Fernández, P.S.; García-Viguera, C.; López-Belchi, M.D. Native species facing climate changes: Response of calafate berries to low temperature and UV radiation. Foods 2021, 10, 196. [CrossRef]

47. Petzold, G.; Orellana-Palma, P.; Moreno, J.; Cerda, E.; Parra, P. Vacuum-assisted block freeze concentration applied to wine. Innov. Food Sci. Emerg. Technol. 2016, 36, 330-335. [CrossRef]

48. Casas-Forero, N.; Orellana-Palma, P.; Petzold, G. Comparative study of the structural properties, color, bioactive compounds content and antioxidant capacity of aerated gelatin gels enriched with cryoconcentrated blueberry juice during storage. Polymers 2020, 12, 2769. [CrossRef]

49. Krapfenbauer, G.; Kinner, M.; Gössinger, M.; Schönlechner, R.; Berghofer, E. Effect of thermal treatment on the quality of cloudy apple juice. J. Agric. Food Chem. 2006, 54, 5453-5460. [CrossRef] [PubMed]

50. Ramirez, J.E.; Zambrano, R.; Sepúlveda, B.; Kennelly, E.J.; Simirgiotis, M.J. Anthocyanins and antioxidant capacities of six Chilean berries by HPLC-HR-ESI-ToF-MS. Food Chem. 2015, 176, 106-114. [CrossRef]

51. Rubilar, R.; Hubbard, R.; Emhart, V.; Mardones, O.; Quiroga, J.J.; Medina, A.; Valenzuela, H.; Espinoza, J.; Burgos, Y.; Bozo, D. Climate and water availability impacts on early growth and growth efficiency of Eucalyptus genotypes: The importance of GxE interactions. For. Ecol. Manag. 2020, 458, 117763. [CrossRef]

52. Agurto, L.; Allacker, K.; Fissore, A.; Agurto, C.; De Troyer, F. Design and experimental study of a low-cost prefab Trombe wall to improve indoor temperatures in social housing in the Biobío region in Chile. Sol. Energy 2020, 198, 704-721. [CrossRef]

53. Ferreira, S.S.; Silva, P.; Silva, A.M.; Nunes, F.M. Effect of harvesting year and elderberry cultivar on the chemical composition and potential bioactivity: A three-year study. Food Chem. 2020, 302, 125366. [CrossRef] [PubMed] 
54. Moreno, F.L.; Raventós, M.; Hernández, E.; Ruiz, Y. Block freeze-concentration of coffee extract: Effect of freezing and thawing stages on solute recovery and bioactive compounds. J. Food Eng. 2014, 120, 158-166. [CrossRef]

55. Wu, Y.Y.; Xing, K.; Zhang, X.X.; Wang, H.; Wang, Y.; Wang, F.; Li, J.M. Influence of freeze concentration technique on aromatic and phenolic compounds, color attributes, and sensory properties of Cabernet Sauvignon wine. Molecules 2017, $22,899$. [CrossRef] [PubMed]

56. Correa, L.J.; Ruiz, R.Y.; Moreno, F.L. Effect of falling-film freeze concentration on bioactive compounds in aqueous coffee extract. J. Food Process Eng. 2018, 41, e12606. [CrossRef]

57. Augusto, T.R.; Scheuermann-Salinas, E.S.; Alencar, S.M.; D'arce, M.A.B.R.; Costa de Camargo, A.; Vieira, T.M.F. Phenolic compounds and antioxidant activity of hydroalcoholic extracts of wild and cultivated murtilla (Ugni molinae Turcz.). Food Sci. Technol. 2014, 34, 667-673. [CrossRef]

58. Rodríguez, K.; Ah-Hen, K.; Vega-Gálvez, A.; López, J.; Quispe-Fuentes, I.; Lemus-Mondaca, R.; Gáñvez-Ranilla, L. Changes in bioactive compounds and antioxidant activity during convective drying of murta (Ugni molinae T.) berries. Int. J. Food Sci. Tech. 2014, 49, 990-1000. [CrossRef]

59. López, J.; Gálvez, A.V.; Rodríguez, A.; Uribe, E. Murta (Ugni molinae Turcz.): A review on chemical composition, functional components and biological activities of leaves and fruits. Chil. J. Agric. Anim. Sci. 2018, 34, 43-56. [CrossRef]

60. Samsuri, S.; Li, T.H.; Ruslan, M.S.H.; Amran, N.A. Antioxidant recovery from pomegranate peel waste by integrating maceration and freeze concentration technology. Int. J. Food Eng. 2020, 16, 20190232. [CrossRef]

61. Casas-Forero, N.; Moreno-Osorio, L.; Orellana-Palma, P.; Petzold, G. Effects of cryoconcentrate blueberry juice incorporation on gelatin gel: A rheological, textural and bioactive properties study. LWT-Food Sci. Technol. 2021, 138, 110674. [CrossRef]

62. Zielinski, A.A.; Zardo, D.M.; Alberti, A.; Bortolini, D.G.; Benvenutti, L.; Demiate, I.M.; Nogueira, A. Effect of cryoconcentration process on phenolic compounds and antioxidant activity in apple juice. J. Sci. Food Agric. 2019, 99, 2786-2792. [CrossRef] [PubMed]

63. Orellana-Palma, P.; Takhar, P.; Petzold, G. Increasing the separation of block cryoconcentration through a novel centrifugal filter-based method. Sep. Sci. Technol. 2019, 54, 786-794. [CrossRef]

64. Orellana-Palma, P.; Petzold, G.; Andana, I.; Torres, N.; Cuevas, C. Retention of ascorbic acid and solid concentration via centrifugal freeze concentration of orange juice. J. Food Qual. 2017, 2017, 5214909. [CrossRef] 